\title{
Effect of cadmium and arsenic contamination on element content and effectiveness in rhizosphere soils of different forages
}

\author{
Na Jiang ${ }^{1,2}$, Jingmin Yang ${ }^{1}$, Zhihong Huang ${ }^{3}$, Yuan $\mathrm{Li}^{1}$ and Yanqun $\mathrm{Zu}^{1, a}$ \\ ${ }^{1}$ College of Resources and Environment, Yunnan Agricultural University, 650201 Kunming, Yunnan, China \\ ${ }^{2}$ College of Animal Science and Technology, Yunnan Agricultural University, 650201 Kunming, Yunnan, China \\ ${ }^{3}$ Shengqing environmental protection Co., Ltd, Kunming, China
}

\begin{abstract}
To explore the effects of $\mathrm{Cd}$ and As composite contaminated soils on the element contents and effectiveness in rhizosphere soils of different forages, the root morphology, rhizosphere soil elements and their availability of 21 forages were studied and analyzed. The results showed: The 21 cultivars showed significant differences in root morphological characteristics. Root length is an index of root morphology that has the highest correlation with other elements and availability. And the correlation between the availability of each element and root morphology was higher than that of element content. Among them, $\mathrm{Fe}$ availability was significantly correlated with root morphological characteristics $(P<0.05)$. The contents of different elements and availability varied greatly among the different cultivars. Among the six rhizosphere soil elements, the difference of toxic metal $\mathrm{Cd}$ was the largest, while the difference of Al availability was the largest. According to the correlation analysis between the elements and availability of each cultivar, the interaction of the availability of each element is higher than that of the soil element under the composite contaminated of $\mathrm{Cd}$ and As. Toxic metals $\mathrm{Cd}$ and As affected each other, and there was a very significant positive correlation between the content and availability. Fe, Mn and $\mathrm{P}$ had higher correlation with $\mathrm{Cd}$ and As.
\end{abstract}

\section{Introduction}

Toxic metal pollution is one of the important research problems in soil ecological remediation, which is shown not only by single element pollution, but also by two or even multi-element compound pollution ${ }^{[1]}$. Among them, the problem of cultivated land caused by $\mathrm{Cd}$ and $\mathrm{As}$ combined pollution is causing more and more economic losses to China. These two elements have a wide range of pollution and great toxicity. However, there are complex additions, synergism and antagonism between soil and organisms, which makes the impact of their combined pollution on the environment more complex than that of single pollution. The interaction between different metal elements also provides a new idea for biological detoxification and metal pollution remediation $^{[2-3]}$. The interaction between metal and other elements is very complex under the stress of metal compound pollution, which will show different forms of action due to the existence of different elements. At present, the research on $\mathrm{Cd}$ and As compound polluted soil mainly focuses on the different absorption of toxic elements by cultivated varieties ${ }^{[4-5]}$. There are relatively few studies on the effects of metal pollution elements in soil on root morphology and the content of other elements in soil, which need to be studied.

Gejiu City, Yunnan Province is an industrial city rich in mineral resources. The problems left by the early mining and metallurgy are the main sources of $\mathrm{Cd}$ and As pollution in the local soil. According to the investigation, the local characteristic dairy industry has developed into a regular model, forages is the main forage crop. Therefore, 21 forages cultivars planted locally were used as test materials on the farmland soil polluted by $\mathrm{Cd}$ and $\mathrm{As}$. The root morphological characteristics, different element contents and effective statuses of the forages cultivars were investigated to explore the interaction between each element under $\mathrm{Cd}$ and As composite contaminated soils. It is hoped to provide a basis for the future regulation of toxic metal elements in contaminated soils and the safe prevention and control during forages production in agricultural fields.

\footnotetext{
${ }^{\text {a }}$ Corresponding author: zuyanqun@ynau.edu.com
} 


\section{Materials and methods}

\subsection{Experimental site location and forage plants}

The experimental area was located Zhadian District, Jijie Town, Gejiu City, Yunnan Province, with an altitude of $1428 \mathrm{~m}, 103^{\circ} 15^{\prime} \mathrm{E}$ and $23^{\circ} 46^{\prime} \mathrm{N}$. Soil physical and chemical properties: The $\mathrm{pH}$ between 7.64-8.19, 40.26 $\mathrm{g} / \mathrm{kg}$ of organic content, $2.54 \mathrm{~g} / \mathrm{kg}$ of total nitrogen content, $1.36 \mathrm{~g} / \mathrm{kg}$ of total phosphorus content, $2.26 \mathrm{~g} / \mathrm{kg}$ of total potassium content, $142.23 \mathrm{mg} / \mathrm{kg}$ of alkalihydrolyzable nitrogen content, $179.5 \mathrm{mg} / \mathrm{kg}$ of available phosphorus content, $178.91 \mathrm{mg} / \mathrm{kg}$ of available potassium, $5.09 \mathrm{mg} / \mathrm{kg} \mathrm{Cd}$ and $226.13 \mathrm{mg} / \mathrm{kg} \mathrm{As}$, respectively. The contents of $\mathrm{Cd}$ and $\mathrm{As}$ in the experimental area exceeded the control values of soil pollution risk of agricultural land in "Soil environmental quality risk control standard for soil contamination of agricultural land" (GB 15618-2018) by 1.27 times and 2.26 times, which belonged to severe pollution.

The tested materials were 21 cultivars of forages mainly comprising 3 families (Gramineae, Leguminosae, and Compositae), including 18 species and 21 cultivars (Table 1.).

Table 1. Species, families and genera of forages materials.

\begin{tabular}{|c|c|c|c|}
\hline Number & Cultivar & Species & Family \\
\hline 1 & Farn & Festuca arundinacea Schreb. & Gramineae \\
\hline 2 & Denata & Dactylis glomerata L. & Gramineae \\
\hline 3 & Reyan 4 & $\begin{array}{l}\text { Pennisetum purpureum } \text { Schumach. } \times \text { Pennisetum } \\
\text { glaucum }(\mathrm{L} .) \mathrm{R} . \mathrm{Br} .\end{array}$ & Gramineae \\
\hline 4 & Pearl millet & Pennisetum alopecuroides (L.) Spreng. & Gramineae \\
\hline 5 & Ye Min & Phleum pratense $\mathrm{L}$. & Gramineae \\
\hline 6 & De & Secale cereale $\mathrm{L}$. & Gramineae \\
\hline 7 & $\mathrm{Mu}$ & Pennisetum giganteum z.x.lin & Gramineae \\
\hline 8 & VNS & Coronilla varia $\mathrm{L}$. & Leguminosae \\
\hline 9 & Bondi & Lolium Multiflorum $\mathrm{L}$. & Gramineae \\
\hline 10 & Maddy & Lolium perenne $\mathrm{L}$. & Gramineae \\
\hline 11 & Super King Tang & Sorghum bicolor $\times$ S. Sudanense & Gramineae \\
\hline 12 & 12SU9001 & Sorghum bicolor $\times$ S. Sudanense & Gramineae \\
\hline 13 & & Sorghum sudanense (Piper) Stapf. & Gramineae \\
\hline 14 & 12 & Sorghum sudanense (Pip & Gramineae \\
\hline 15 & 13FB7001 & Sorghum bicolor (L.) Moench & Gramineae \\
\hline 16 & & Sorghum bicolor (L.) Moench & Gramineae \\
\hline 17 & WL525HQ & Medicago Sativa L. & Leguminosae \\
\hline 18 & Grand Slam & Cichorium pumilum Jacq. & Compositae \\
\hline 19 & You-12 & Zea mays ssp. mexicana & Gramineae \\
\hline 20 & Rainbow & Pennisetum purpureum Schum cv.Guiminyin & Gramineae \\
\hline 21 & Chaosheng & Lactuca indica $\mathrm{L}$. & Compositae \\
\hline
\end{tabular}

\subsection{Experimental design}

The test materials were sown in October 2019. In the insitu field test, each material was set up with three replicates. The plot area was $3 \mathrm{~m} \times 5 \mathrm{~m}$, and the materials were randomly distributed. In the in-situ field test, each material was set up with three groups of repetition, the plot area was $3 \mathrm{~m} \times 5 \mathrm{~m}$, and the materials were randomly distributed. During the growth period, insecticidal, weeding, watering and topdressing were carried out according to the growth status. Samples were collected in June 2020. Five sampling sites were sampled evenly and randomly by " $\mathrm{X}$ " method, and the plant root and rhizosphere soil samples were collected. The aboveground and underground parts of the plant were opened with scissors and put into polyethylene bags.

\subsection{Determination of root morphology}

The plant root scanner EPSON perfection V700 photo was used for scanning and analysis.

\subsection{Determination of element content and available state in rhizosphere soil}

The content of cadmium was determined by flame atomic absorption spectrometry (Thermo ICE 3000 SERIES) and recorded it in $\mathrm{mg} / \mathrm{kg}^{[6-7]}$. The content of arsenic was determined by atomic fluorescence spectrometer (AFS-9710) and recorded it in $\mathrm{mg} / \mathrm{kg}^{[8-9]}$. Determination of total phosphorus and available phosphorus in soil by molybdenum antimony anti colorimetric Spectrophoto-metry (Metash UV-5800) ${ }^{[6]}$. The content and effective state of $\mathrm{Fe}, \mathrm{Mn}$ and $\mathrm{Al}$ were determined by ICP-OES (ThermoScientific iCAP6300) [6. 10].

\subsection{Statistical analyses}

The statistical significance analyzed used one-way analysis of variance (ANOVA) and Duncan test the difference of the average value of different treatments at the 0.05 level by SPSS $20.0(n=3)$. And the correlation was analyzed by Spearman method.

\section{Results}

\subsection{Differences in rhizosphere soil $\mathrm{pH}$ and root morphology}

The rhizosphere soil $\mathrm{pH}$ of the 21 cultivars ranged from 7.33 to 8.70 , and the differences were not significant $(P>0.05)$, whereas obvious differences were observed in root morphology among the different cultivars (Table 2.). The maximum difference of total root length was 13.41 times, the maximum value was 'Denata' of Gramineae, and the minimum value was 'Grand slam' of Compositae, and the maximum differences of root length, root surface area, root volume and root diameter among cultivars were $1.97,6.26,30.82$ and 179.3 times, respectively. Except for root length, the maximum value is Compositae. 
Table 2. Soil pH and root morphology in the Rhizosphere of 21 cultivars.

\begin{tabular}{|c|c|c|c|c|c|c|}
\hline Cultivar & $\mathrm{pH}$ & $\begin{array}{l}\text { total root length } \\
(\mathrm{cm})\end{array}$ & $\begin{array}{l}\begin{array}{l}\text { root length } \\
(\mathrm{cm})\end{array} \\
\end{array}$ & $\begin{array}{c}\text { root surface area } \\
\left(\mathrm{cm}^{2}\right)\end{array}$ & $\begin{array}{l}\text { root diameter } \\
(\mathrm{mm})\end{array}$ & $\begin{array}{c}\text { root volume } \\
\left(\mathrm{cm}^{3}\right)\end{array}$ \\
\hline Farn & $7.73 \pm 0.07 \mathrm{a} 2$ & $210.94 \pm 52.21 \mathrm{efg}$ & $8.68 \pm 2.09 \mathrm{~d}$ & $28.96 \pm 8.83 \mathrm{~h}$ & $0.43 \pm 0.04 \mathrm{~d}$ & $0.3 \pm 0.13 \mathrm{c}$ \\
\hline Denata & $\pm 0.04 \mathrm{a}$ & $681.71 \pm 160.46 \mathrm{a}$ & $11.63 \pm 2.52 \mathrm{~cd}$ & $125.67 \pm 28.13 \mathrm{abcde}$ & $0.48 \pm 0.02 \mathrm{~d}$ & $1.49 \pm 0.3 \mathrm{c}$ \\
\hline Reyan 4 & $8.27 \pm 0.02 \mathrm{a} 6$ & $619.69 \pm 112.16 \mathrm{ab}$ & $17.85 \pm 0.88 \mathrm{a}$ & 113.94 27. labedef & $0.58 \pm 0.04 \mathrm{~cd}$ & $1.68 \pm 0.51 \mathrm{c}$ \\
\hline Pearl millet & $8.02 \pm 0.09 \mathrm{a} 3$ & $397.92 \pm 36.45 \mathrm{bcde}$ & $11.89 \pm 2.11 \mathrm{bcd}$ & $74.03+10.86$ defgh & $0.59 \pm 0.04 \mathrm{~cd}$ & $1.11 \pm 0.23 \mathrm{c}$ \\
\hline Ye Mingzhu & $8.00 \pm 0.12 \mathrm{a}$ & $370.36 \pm 78.34 \mathrm{de}$ & $11.79 \pm 1.02 \mathrm{bcd}$ & $41.66 \pm 5.32 \mathrm{fgh}$ & $0.38 \pm 0.06 \mathrm{~d}$ & $0.39 \pm 0.09 \mathrm{c}$ \\
\hline Dongmu-70 & $7.46 \pm 0.10 \mathrm{a} 3$ & $301.13 \pm 21.73 \mathrm{def}$ & $13.5 \pm 0.6 \mathrm{abcd}$ & $52.4 \pm 14.97 \mathrm{efgh}$ & $0.55 \pm 0.16 \mathrm{~cd}$ & $0.84 \pm 0.45 \mathrm{c}$ \\
\hline Munzhou I & $8.13 \pm 0.03 a 6$ & $611.69 \pm 170.39 \mathrm{abc}$ & $15.31 \pm 1.61 \mathrm{abc}$ & $151.24 \pm 13.62 \mathrm{abc}$ & $0.62 \pm 0.11 \mathrm{~cd}$ & $1.9 \pm 0.6 \mathrm{c}$ \\
\hline vNS & $8.07 \pm 0.05 \mathrm{a} 4$ & $411.66 \pm 66.17$ & $15.14 \pm 1.28 \mathrm{abc}$ & $107.97 \pm 9.56$ abcdefg & $0.89 \pm 0.17 \mathrm{~cd}$ & $2.4 \mathrm{I} \pm 0.5 \mathrm{lc}$ \\
\hline Bondi & $8.00 \pm 0.00 \mathrm{a} 2$ & $273.13 \pm 9.89 \mathrm{defg}$ & $12.48 \pm 1.09 \mathrm{bcd}$ & $33.22 \pm 3.67 \mathrm{gh}$ & $0.39 \pm 0.05 \mathrm{~d}$ & $0.33 \pm 0.08 \mathrm{c}$ \\
\hline Maddy & $8.11 \pm 0$. & $431.44 \pm 99.5 \mathrm{bcde}$ & $8.87 \pm 0.32 \mathrm{~d}$ & $53.42 \pm 12.3 \mathrm{efgh}$ & $0.39 \pm 0.01 \mathrm{~d}$ & $0.53 \pm 0.12 \mathrm{c}$ \\
\hline Super King Tang & $8.01 \pm 0.01 \mathrm{a}$ & $350.36 \pm 6.32 \mathrm{de}$ & $14.29 \pm 1.49 \mathrm{abc}$ & $114.47 \pm 1.2 \mathrm{abcdef}$ & $1.04 \pm 0.01 \mathrm{~cd}$ & $2.98 \pm 0.05 \mathrm{c}$ \\
\hline 12SU9001 & $7.90 \pm 0.03 \mathrm{a} 2$ & $279.56 \pm 28.65 \mathrm{defg}$ & $14.29 \pm 1.49 \mathrm{abc}$ & $78.79 \pm 6.54$ cdefgh & $0.90 \pm 0.05 \mathrm{~cd}$ & $1.78 \pm 0.16 \mathrm{c}$ \\
\hline 12SU9003 & $7.62 \pm 0.05 \mathrm{a} 2$ & $200.82 \pm 37.54 \mathrm{efg}$ & $12.38 \pm 1.57 \mathrm{bcd}$ & $51.44 \pm 8.64 \mathrm{efgh}$ & $0.84 \pm 0.09 \mathrm{~cd}$ & $1.07 \pm 0.2 \mathrm{c}$ \\
\hline 12SU9004 & $8.13 \pm 0.04 a 2$ & $279.49 \pm 14.29 \mathrm{defg}$ & $12.4 \pm 2.22 \mathrm{bcd}$ & $95.41 \pm 8.74 \mathrm{bcdefgh}$ & $1.09 \pm 0.1 \mathrm{~cd}$ & $2.64 \pm 0.45 \mathrm{c}$ \\
\hline $13 \mathrm{E}$ & $7.82 \pm 0.19 \mathrm{a} 4$ & $467.84 \pm 38.72 \mathrm{abcd}$ & $14.41 \pm 0.39 \mathrm{abc}$ & $134.12 \pm 18.27 \mathrm{abcd}$ & $0.91 \pm 0.08 \mathrm{~cd}$ & $3.11 \pm 0.65 \mathrm{c}$ \\
\hline $12 \mathrm{FS} 9003$ & $7.48 \pm 0.03 \mathrm{a} 3$ & $384.67 \pm 53.46 \mathrm{cde}$ & $16.31 \pm 0.52 \mathrm{abc}$ & $153.14 \pm 29.23 \mathrm{abc}$ & $1.25 \pm 0.1 \mathrm{~cd}$ & $4.9 \pm 1.19 \mathrm{c}$ \\
\hline WL525HQ & $7.68 \pm 0.05 \mathrm{a} 2$ & $281.75 \pm 39.49 \mathrm{defg}$ & $17.14 \pm 0.89 \mathrm{ab}$ & $148.21+53.75$ abcd & $1.60 \pm 0.43 \mathrm{c}$ & $3.73+1.03 \mathrm{c}$ \\
\hline Grand Slam & $8.03 \pm 0.03 a$ & $50.84 \pm 11.02 \mathrm{~g}$ & $11.51 \pm 3.28 \mathrm{~cd}$ & $158.32 \pm 55.72 \mathrm{ab}$ & $11.71 \pm 0.6 \mathrm{a}$ & $46.98 \pm 17.68 \mathrm{~b}$ \\
\hline You-12 & $7.58 \pm 0.02 \mathrm{a} 2$ & $246.25 \pm 26.03 \mathrm{defg}$ & $15.05 \pm 1.57 \mathrm{abc}$ & $117.32 \pm 10 \mathrm{abcdef}$ & $1.10 \pm 0.21 \mathrm{~cd}$ & $2.62 \pm 0.97 \mathrm{c}$ \\
\hline Rainbow & $7.87 \pm 0.12 \mathrm{a} 4$ & $466.04 \pm 71.62 \mathrm{abcd}$ & $16.09 \pm \mathrm{labc}$ & $144.36 \pm 15.32 \mathrm{abcd}$ & $0.53 \pm 0.04 \mathrm{~cd}$ & $1.48 \pm 0.42 \mathrm{c}$ \\
\hline Chaosheng & $7.73 \pm 0.05 \mathrm{a}$ & $72.24+1.1 \mathrm{fg}$ & $14.12 \pm 0.84 \mathrm{abc}$ & $181.37 \pm 23.41 \mathrm{abcd}$ & $9.08 \pm 1.16 \mathrm{~b}$ & $53.79 \pm 15.24 \mathrm{a}$ \\
\hline
\end{tabular}

Note: Data are the mean \pm standard errors of three replicates. Different lowercase letters represent significant differences between data in the same column $(P<0.05)$.

\subsection{Difference of element content in rhizosphere soil}

There were differences in the contents of different elements in the rhizosphere soil of different forage grasses (Figure 1.). The $\mathrm{Cd}$ and $\mathrm{P}$ contents in soil of 'Denata' was the highest. The highest contents of As, Fe, $\mathrm{Mn}$ and Al were 'You-12', 'Reyan 4', 'Faren' and 'Grand Slam', respectively, with significant difference $(P<0.05)$. After planting 'Reyan 4', the contents of $\mathrm{Cd}$, As and $\mathrm{Mn}$ in rhizosphere soil were the lowest, the lowest contents of Fe were 'denata' and 'Dongmu-70', the lowest contents of $\mathrm{Al}$ were made in China, and the lowest contents of P were 'Munzhou I'. Among the six rhizosphere soil elements, the biggest difference was the $\mathrm{Cd}$ content, and the difference reached 4.76 times.
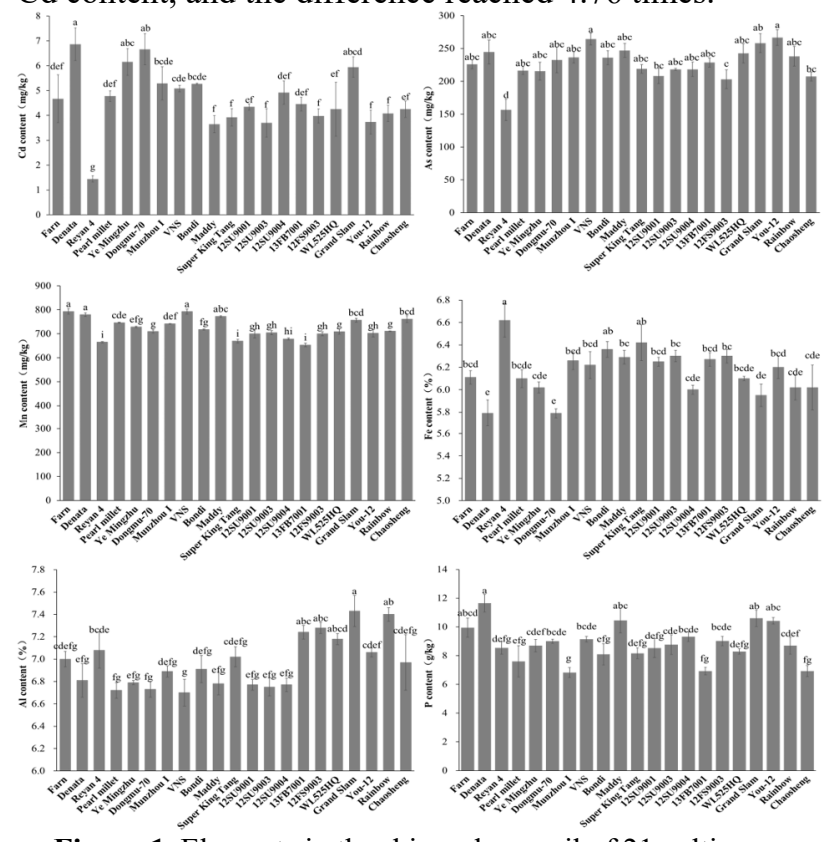

Figure 1. Elements in the rhizosphere soil of 21 cultivars.

\subsection{Difference of effective content of elements in rhizosphere soils}

The highest availability of As and $\mathrm{P}$ was found in 'Denata' (Figure 2.), the lowest in 'Super King Tang' and '12SU9004', respectively. And 'Yemingzhu', 'Dongmu 70' and 'Super King Tang' had the highest availability of $\mathrm{Cd}, \mathrm{Mn}$ and $\mathrm{Al}$, while 'You-12', 'Reyan 4' and 'VNS' had the lowest. Moreover, The highest availability of Fe was 'Reyan 4', the lowest was 'denata' and 'Dongmu-70'. There were significant differences in rhizosphere soil availability among different cultivars, and the biggest difference among these available states was $\mathrm{Al}$ availa- bility, which was 4.22 times higher than that in rhizosphere soil of different cultivars.
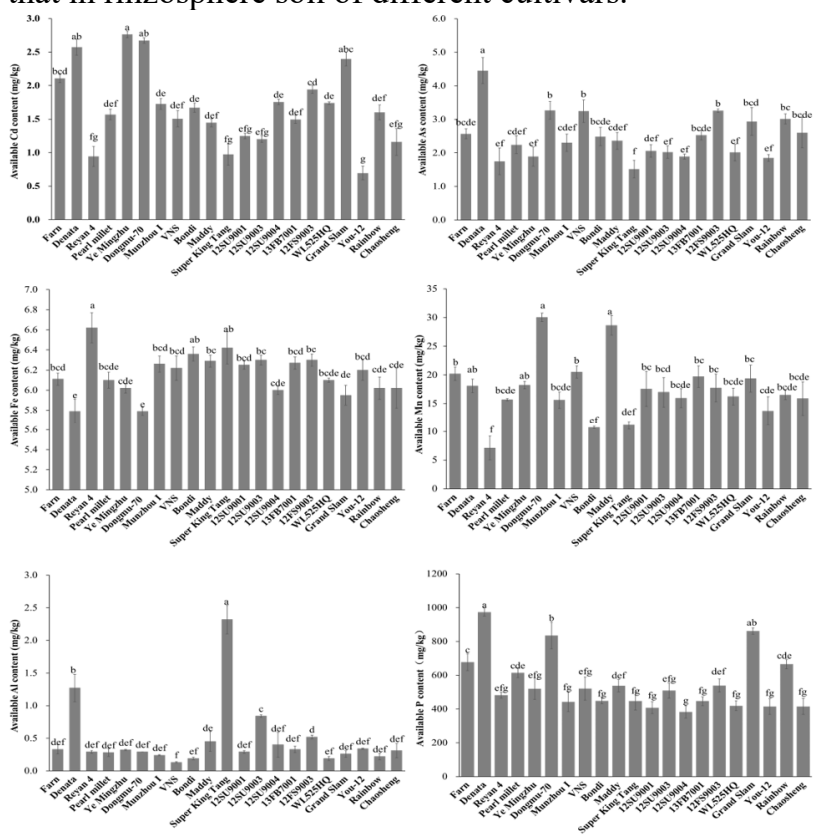

Figure 2. Availability of elements in the rhizosphere soil of 21 cultivars.

\subsection{Correlation analysis}

The root morphology of forages was not significantly correlated with the content of $\mathrm{Cd}$ and As, the same as the soil $\mathrm{pH}$ (Table 3-5.). But the $\mathrm{pH}$ was significantly correlated with the As availability, and the root length was negatively correlated with the available state of $\mathrm{Cd}$, $\mathrm{Fe}, \mathrm{Mn}$ and $\mathrm{P}(P<0.05)$. The contents of $\mathrm{Cd}$ and $\mathrm{As}$ were significantly positively correlated with the available state of $\mathrm{Cd}$ and $\mathrm{As}$, and both of them were significantly correlated with $\mathrm{Fe}, \mathrm{Mn}$ content and availability. $(P<0.05)$. There was extremely significant positive correl-ation between $\mathrm{Cd}$, As availability and $\mathrm{P}$ availability $(P<0.01)$. The correlation of the available state of each element to the root morphology in the soil polluted by $\mathrm{Cd}$ and As was higher than that of the element content, and the interaction of the available state of each element was higher than that of the soil element. 
Table 3. Correlation analysis between root morphology and soil elements among 21 cultivars.

\begin{tabular}{ccccccc}
\hline & $\mathrm{pH}$ & Total root length & Root length & Root surface area & Root diameter & Root volume \\
\hline Cd content & -0.171 & -0.051 & -0.222 & -0.002 & 0.090 & 0.096 \\
As content & -0.157 & -0.104 & -0.004 & 0.120 & 0.081 & 0.085 \\
Fe content & $0.305^{*}$ & 0.090 & 0.154 & -0.098 & $-0.276^{*}$ & $-0.297^{*}$ \\
Mn content & 0.012 & -0.065 & $-0.359^{* *}$ & -0.095 & 0.203 & 0.189 \\
Al content & -0.052 & -0.137 & 0.151 & $0.373^{* *}$ & $0.303^{*}$ & 0.175 \\
P content & -0.088 & -0.015 & $-.0278^{*}$ & -0.111 & 0.036 & 0.013 \\
Cd availability & -0.231 & -0.019 & $-0.294^{*}$ & -0.092 & 0.084 & 0.047 \\
As availability & $-0.303^{*}$ & 0.153 & -0.134 & 0.130 & 0.127 & 0.134 \\
Fe availability & -0.090 & 0.071 & $-0.264^{*}$ & $-0.291^{*}$ & $-0.288^{*}$ & $-0.258^{*}$ \\
Mn availability & -0.233 & -0.088 & $-0.298^{*}$ & -0.172 & 0.028 & 0.072 \\
Al availability & -0.047 & 0.086 & -0.123 & 0.010 & -0.100 & -0.085 \\
P availability & -0.237 & 0.066 & $-0.291^{*}$ & -0.033 & 0.177 & 0.120
\end{tabular}

Note: *At the 0.05 level, correlations were significant.

** At the 0.01 level the correlation was extremely significant. The same below.

Table 4. Correlation analysis of the content of elements in rhizosphere soil of 21 cultivars.

\begin{tabular}{ccccccc}
\hline & $\mathrm{Cd}$ & $\mathrm{As}$ & $\mathrm{Fe}$ & $\mathrm{Mn}$ & $\mathrm{Al}$ & $\mathrm{P}$ \\
\hline $\mathrm{Cd}$ & 1 & & & & & \\
$\mathrm{As}$ & $0.358^{* *}$ & 1 & & & & \\
$\mathrm{Fe}$ & $-0.632^{* *}$ & $-0.257^{*}$ & 1 & & & \\
$\mathrm{Mn}$ & $0.375^{* *}$ & $0.351^{* *}$ & $-0.320^{*}$ & 1 & & \\
$\mathrm{Al}$ & -0.207 & 0.039 & $0.284^{*}$ & -0.212 & 1 & \\
$\mathrm{P}$ & 0.102 & 0.205 & $-0.264^{*}$ & $0.297^{*}$ & -0.002 & 1 \\
\hline
\end{tabular}

Table 5. Correlation analysis of availability in rhizosphere soil of 21 cultivars.

\begin{tabular}{ccccccc}
\hline & $\mathrm{Cd}$ & $\mathrm{As}$ & $\mathrm{Fe}$ & $\mathrm{Mn}$ & $\mathrm{Al}$ & $\mathrm{P}$ \\
\hline $\mathrm{Cd}$ & 1 & & & & & \\
$\mathrm{As}$ & $0.469^{* *}$ & 1 & & & & \\
$\mathrm{Fe}$ & $0.463^{* *}$ & $0.306^{*}$ & 1 & & & \\
$\mathrm{Mn}$ & $0.415^{* *}$ & $0.380^{* *}$ & $0.521^{* *}$ & 1 & & \\
$\mathrm{Al}$ & -0.085 & -0.040 & -0.145 & -0.159 & 1 & \\
$\mathrm{P}$ & $0.628^{* *}$ & $0.593^{* *}$ & $0.325^{* *}$ & $0.409^{* * *}$ & 0.115 & 1 \\
\hline
\end{tabular}

\section{Discussions}

Roots showed a high degree of plasticity to changes of soil environmental factors during the growth process. Difference in genotype and growing environment can lead to changes in morphological characteristics of part or the whole root system ${ }^{[11]}$. Metal ions on the root surface can be absorbed actively and passively through cation exchange, diffusion and metabolic energy, and show a high selectivity to some metal elements ${ }^{[12]}$. Larger root morphological characteristics, such as root length, root surface area, root volume and root tip number, not only help to increase the contact area between plant roots and soil, and promote roots to absorb trace elements in soil. It may also increase the absorption and accumulation of metal elements ${ }^{[13]}$. In this experiment, the effect of $\mathrm{pH}$ on the rhizosphere soil of all forage cultivars before and after planting was small. There were significant differences in total root length, root surface area, root diameter and root volume among different forages, and the degree of difference varied with cultivars, which was consistent with the results of
Gao et al. ${ }^{[14]}$. In root morphology, the total root length and root length of Gramineae were generally higher than those of Leguminosae and Compositae, while the root surface area, root diameter and root volume of Compositae were higher than those of Gramineae and Leguminosae, which was mainly related to the growth characters and interspecific differences of each material. Li et al. ${ }^{[15]}$ also shows that the change in root form structure is an important embodiment of plant adaptation to stress. In addition, correlation analysis showed that there was a significant correlation between $\mathrm{Fe}$ availability and root morphology, and it was found that root length had more correlation with the content of Mn, $\mathrm{P}$ and the available state of $\mathrm{Cd}, \mathrm{Fe}, \mathrm{Mn}$, which fully indicated that root length was a very important index in $\mathrm{Cd}$ and As contaminated soil, which may be more affected by some trace elements and $\mathrm{Cd}$.

There are complex additive, synergistic and antagonistic effects between soil and organisms, which makes the impact of metal compound pollution on the environment more complex than that of single pollution ${ }^{[16]}$. Cd and As exist in different forms in soil with different migration characteristics and bioavailability. After $\mathrm{Cd}$ and As enter the soil environment, the interaction between soil $\mathrm{pH}$, and hazardous metals is an important influencing factor ${ }^{[17]}$. Studies have shown that toxic elements tend to affect mineral elements in soils ${ }^{[18-}$ ${ }^{19]}$. However, the contents of both toxic metals including $\mathrm{Cd}$ and As showed extremely significant positive correlation in this experiment $(P<0.01)$, and it indicated that the interaction had a large effect and showed a synergistic relationship. Guo et al. ${ }^{[20]}$ reported that the coexistence of $\mathrm{Cd}$ and As in soil could additive to alfalfa, and $\mathrm{Cd}$ promote the accumulation of As. At the same time, the toxic elements were positively correlated with Fe content and negatively correlated with Mn content, but the effectiveness was positively correlated with the available state of $\mathrm{Fe}, \mathrm{Mn}$ and $\mathrm{P}$, which had obvious synergistic effect. This result suggests that increased or accumulated nutrients such as $\mathrm{Fe}$ and $\mathrm{P}$ in soils may exacerbate the risk of $\mathrm{Cd}$ or As contamination in cultivated forages. The interactive interaction between $\mathrm{Cd}$, As and each element is an important factor affecting the absorption and accumulation of the pollutants toxic metals in soils by forages. It is similar to that of Cheng et al. ${ }^{[21]}$.

\section{Conclusions}

There were significant differences in root morphology among different cultivars, and the root length was more affected by some trace elements and $\mathrm{Cd}$ in the composite contaminated soils. The correlation between the available state of each element and root morphology was higher than that of element content, and the available state of rhizosphere soil elements had a greater effect on plant root morphology. There was a significant positive correlation between $\mathrm{Cd}$ and $\mathrm{As}$, and the interaction was synergistic. At the same time, in the element content of rhizosphere soil, the difference of $\mathrm{Cd}$ content was the biggest, while in the available state, the difference of $\mathrm{Al}$ 
content was the biggest. The elements with high correlation with metal $\mathrm{Cd}$ and $\mathrm{As}$ are $\mathrm{Fe}, \mathrm{Mn}$ and $\mathrm{P}$. The results can provide a certain scientific basis for the selection of agricultural cultivars of farmland polluted by hazardous metals in mining area and the appropriate measures to control the pollution of $\mathrm{Cd}$ and $\mathrm{As}$ in farmland soil, and realize the effective control and safe utilization.

\section{Acknowledgments}

This work was supported by the Key R\&D Projects of Yunnan Province (grant No. 2019BC001-04).

\section{References}

1. Yao, B., Yang, A.P., Chen, H.Y., et al. (2020) Ssil heavy metal pollution and risk assessment of agricultural soils in the Yunnan-Guizhouarea, Upper Pearl River Basin. Journal of Agro-Environment Science. 39(10): 2259-2266.

2. Li, Y., Shang, J.Y., Huang, Y.Z., et al. (2020) Research progress of passivation materials in cadmium-arsenic contaminated soil. Acta Pedologica sinica.1-12.

3. He, Y.L. (2020) Speciation and bioavailability of cadmium and arsenic in soils. Journal of Green Science and Technology. 10: 108-109+112.

4. Shan, T.Y., Liu, Q.X., Yan, X.L., et al. (2017) Cd and As absorption and transport characteristics of rice in a paddy field co-contaminated by $\mathrm{Cd}$ and $\mathrm{As}$. Journal of Agro-Envirornment Science. 36(10): 1938-1945.

5. Zhao, D.B., Cao, Z., She, W., et al. (2015) Effects of $\mathrm{Cd}$, As stress on growth and $\mathrm{Cd}$, As uptake of Ramie ( Boehmeria nivea L. ). Plant fiber sciences in China., 37(04): 183-188.

6. Bao, S.D. (2005) Agricultural soil analysis. Chinese Agricultural Press. Beijing.

7. National environmental protection standards of the people's Republic of China. (2009) GBT237392009GB Soil quality-Analysis of available lead and cadmium contents in soils-Atomic absorption spectrometry. Standardization Administration of China.

8. National environmental protection standards of the people's Republic of China. (2008) GBT22105.22008 Soil quality-Analysis of total mercury, arsenic and lead contents-Atomic fluorescence spectrometry. Standardization Administration of China.

9. Yang, Y.P., Wang, P., Yan, H.J., et al. (2019) NH4H2PO4-extractable arsenic provides a reliable predictor for arsenic accurmulation and speciation in pepper futs(Capsicum annum L.). Environmental Pollution. 251:651-658.

10. National environmental protection standards of the people's Republic of China. (2016) HJ804-201Soil Determination of bioavailable form of eight elements -Extraction withbuffered DTPA solution/Inductively coupled plasma optical emission spectrometry. China Environmental Science Press: issued by Ministry of environmental protection.

11. Ostonen, I., Pittsepp, U., Biel, C., et al. (2007) Specific root length as an indicator of environmental change. Plant Biosystems-An International Journal Dealing with all Aspects of Plant Biology. 141(3): 426-442.

12. Wang, X.J., Wang, W.B.,Yang, L., et al. (2015) Transport pathways of cadmium $(\mathrm{Cd})$ and its regulatory mechanisms in plant. Acta Ecologica Sinica. 35(23): 7921-7929.

13. Lu, Z.W., Zhang, Z., Su, Y., et al. (2013) Cultivar variation in morphological response of peanut roots to cadmium stress and its relation to cadmium accumulation. Ecotoxicology and Environmental Safety. 91(4): 147. DOI: 10.1016/j.ecoenv.2013.01. 017.

14. Gao, Q.L., Zhen, R.L., Li, H.F. (2010) Effects of transpiration rate and root character on cadmium absorption by pakchoi cultivars. Chinese Journal of Ecology. 29(09): 1794-1798.

15. Li, J.H., Xu, C.Y., Zhu, J.Y., et al. (2019) Phenotypic Adaptation Strategy of Cotinus coggygria Seedlings in Continuous Drought Environments. Journal of Northwest Forestry University. 34(2): 28-34.

16. Gu, J.F., Zhou, H., Yang, W.T., et al. (2016) Effect of Combined Soil Amendment Regulating Chemical Forms of Cadmium and Arsenic in Paddy Soil and Their Bioaccumulation and Translocation in Rice. Acta Pedologica sinica. 53(6): 1576-1585.

17. Zhou, L., Zhen, X.Q., Ding, Y.Z., et al. (2017) Probes of porevention and contrml of famland poluation by cadinium \& arsenic and crmp prowhuctonsafety. Journal of Agro-Environment Science. 36(4): 613-619.

18. Norton, G.J., Dasgupta, T.M., Islam, M.R., et al. (2010) Arsenic influence on genetic variation in grain trace-element nutrient content in Bengal Delta grown rice.Environmental science \& Technology. 44: 8284-8288.

19. Li, H.F., Zhen, Z.Y., Zhang, F.S., et al. (1999) Effect of iron on the uptake of $\mathrm{Cd}$ from different compounds by wheat plants. Acta Ecologica Sinica. 19(2): 170-173.

20. Yang, Z.M., Zhen, S.J., Hu, A.T., et al. (1999) Research Progress on interaction between phosphorus and heavy metal elements zinc and cadmium in plants. Plant Nutrition and Fertilizer Science. 5(4): 366-376.

21. Ye, W.L., Li, L.L., Lu H.J., et al. (2015) Effet of zinc fertilization on cadmium and arsen ic accumulation in wheat. J Environm en talScience \& Technology. 38(7): 17-20. 
22. Guo, G.L., Zhou, Q.X., Li, X.Y. (2005) Advances in research on in situ chemo-immobilization of heavy metals in contaminated soils. Chinese Journal of Applied Ecology. 16(10): 1990-1996.

23. Cheng, D.W., Zhang, G.P., Yao H.G., et al. (2006) Genotypic and environmental variation and their stability of As, Cr, Cd, Ni and Pb Concentrations in the Grains of Japonica Rice. Acta Agronomica Sinica, 32(4): 573-579. 